\title{
Enthralling tales of dental derring-do
}

\author{
By Caroline Holland
}

With his name on some of the most essential textbooks for paediatric dentists as well as scores of research papers, Emeritus Professor Martin Curzon needs no introduction. The story of his early life as a dentist, however, working in the wilds of British Columbia, which were formative to his progression as a seminal figure in the development of the paediatric specialty, has, until now, remained unpublished.

His new book, entitled Teeth, Trees and Totem Poles, sets the record straight, gratifying generations of dental colleagues who were regaled with the prof's stories of derring-do, at the same time as lifting the lid on a remote world.

As a new graduate, the young Martin and his first wife Jenny had planned to work in Nigeria. But a senior colleague of Martin's persuaded them to follow in his footsteps and take up a role as travelling externs in British Columbia. They would be granted a temporary licence for six months and would be paid an hourly rate for treating children aged 3-9 years; they were free to charge any adults who wanted treatment in the limited time that was left to them every week. Martin and Jenny, also newly qualified, applied and were recruited onto the programme.

Everything moved fast and, with their dental instruments and supplies, they were soon being welcomed in Vancouver. They were surprised on arrival, however, to be told they would be given an induction course in the treatment of children. As graduates of UCH dental school, it was not what they expected. Prof Curzon writes: 'Now qualified for over a year we thought we knew how to treat children. We were told that things were rather different here in $\mathrm{BC}$ than in "the old country".

So began a new approach to children's dentistry, including the use of stainless steel crowns, local anaesthetics (dismissed at the time in the UK as far too difficult to use on young children), and rubber dam.

Described by Prof Curzon as his Road to Damascus, it was immediately embraced by him and Jenny. It was the belt and braces approach that he was to bring to Leeds, where he finally settled in 1983, after time spent undertaking postgraduate studies at the Eastman Dental Hospital, New York, a stint at Bristol University and a return to Canada to treat Inuit children on Baffin Island.

When Prof Curzon was appointed Professor of Child Dental Health at Leeds, paediatric dentistry had a low profile in the UK, according to Stephen Fayle, who provides the context for the impact that Professor Curzon had, both on his own career and on paediatric dentistry as a specialty.

Stephen tells the story: 'I went to Leeds to interview for a place on a Masters in Community Dentistry but Prof Curzon told me that the course was not clinical and I should apply instead for an MSc in Paedodontics. "I didn't think you offered that," I told him. "We don't," the Prof replied, "but you could be our guinea pig."

The offer was irresistible and with three

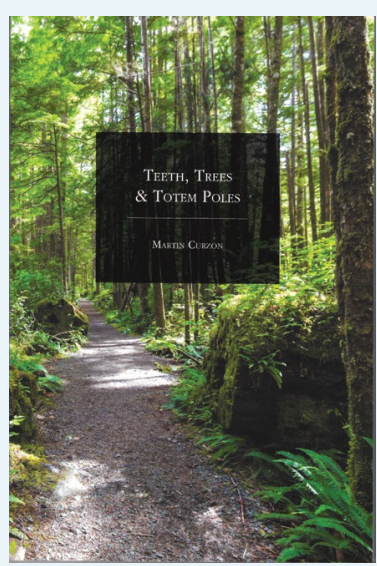

other dentists, Stephen undertook the first Masters in Leeds and went on to work closely with Martin over many years.

Decades later, Professor Curzon is continuing to surprise and educate. The stories in his book of his encounters with loggers, truckers, miners, First Nation peoples, and children, and how he managed to provide their dental treatment, are enthralling.

As friend and colleague Professor Richard Welbury CBE writes in the preface: 'There are many times whilst reading this book that you will smile or laugh at the adventures and experiences of the young dentists. You will develop great respect for their initiative and frontier spirit but most importantly for the respect and care that they gave to their young and older patients. I remain in awe at Martin's data collection records and am very envious that I have never flown in a Curtiss-Wright biplane!'

Copies of this book can be obtained by email at: curzongalphay@btinternet. com or martin@mejbooks.co.uk or 01609 778604. $£ 14.95$ (inc p\&p).

\section{$\mathrm{KCL}$ ranks joint fifth in the world in dentistry}

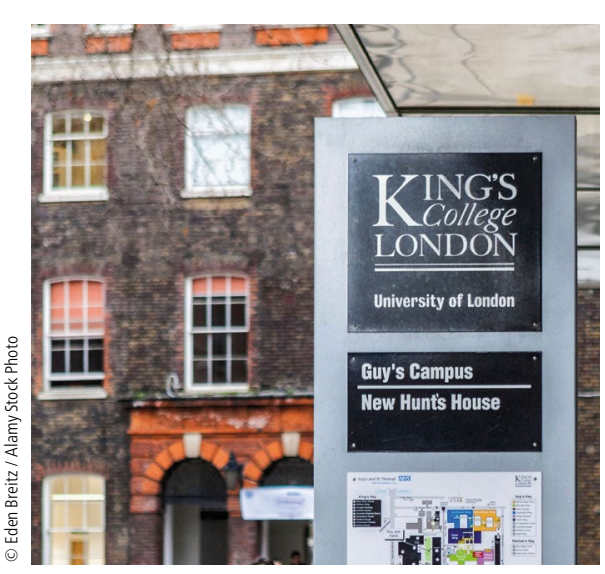

King's College London ranks joint number 5 in the world in dentistry in this year's edition of QS World University Rankings by Subject, a position shared with Tokyo Medical and Dental University.

In first place is the University of Gothenburg followed by the University of Michigan-Ann Arbor, then in joint third, the Academic Centre for Dentistry Amsterdam and The University of Hong Kong.

The QS World University Rankings are among the three best-known university ranking data sets worldwide. The other two are the Academic Ranking of World Universities (ARWU), also known as the Shanghai list, and the Tomes Higher Education (THE).

The QS World University Rankings are produced annually by Quacquarelli Symonds (QS), the higher education analytics company, and are based upon academic reputation, employer reputation and research impact.

To see the full list and find out more, visit https://www.topuniversities.com/universityrankings/university-subject-rankings/2021/ dentistry. 